\title{
Assessment of Antioxidant and Pancreatic Lipase Activity of Smilax zeylanica Roots: An in vitro Analysis
}

\author{
Rosaline Mishra ${ }^{1,2, *}$, Divya Juyal ${ }^{3}$, Sadish Kumar Shanmugham² \\ 'Uttarakhand Technical University, Uttarakhand, INDIA. \\ 2ITS College Ghaziabad, Uttar Pradesh, INDIA. \\ ${ }^{3}$ Roorkee College of Engineering, Roorkee, Uttarakhand, INDIA.
}

\begin{abstract}
Objectives: It is well established fact that the phytochemicals with phenolic and flavonoids origin have antioxidant property. Thus in this study it was aimed to determine the in vitro antioxidant potential of various extracts of Smilax zeylanica L. stems. Methods: The Photochemical screening was done following the standard procedures. The Antioxidant activity was tested using several in vitro assays, viz., 1,1-diphenyl-2-picrylhydrazyl (DPPH) assay. The Total phenol and flavonoid contents were determined by colorimetric method. Further porcine lipase activity was determined. Results: The phytochemical screening revealed the presence of phenols and flavonoids the extracts. The Methanolic extract showed significant antioxidant potential than other extracts in all assays. The $\mathrm{IC}_{50}$ value of cyclo hexane extract, ethyl acetate extract and methanol extract of Smilax zeylanica was $29.14 \pm 0.39 \mu \mathrm{g} / \mathrm{mL}, 78.41 \pm 5.53 \mu \mathrm{g} / \mathrm{mL}$ and $120.30 \pm 3$ $.32 \mu \mathrm{g} / \mathrm{mL}$ respectively in DPPH assay. Porcine pancreatic lipase inhibition
\end{abstract}

assay Ishowed dose-dependent effect. The \% Inhibition of cyclohexane extract (SZH) was $37.52 \% 54.44 \%$ and $77.07 \%$ at the highest dose $200 \mu \mathrm{g} /$ $\mathrm{ml}$. The highest inhibition was obtained in the methanolic extract at $200 \mu \mathrm{g} /$ $\mathrm{ml}$ conc which was close to the standard orlistat i.e. 82.39 at $200 \mu \mathrm{g} / \mathrm{ml}$. Conclusion: The methanolic extracts showed potential pancreatic lipase inhibition.

Key words: Antioxidant activity, DPPH, Smilax zeylanica, Pancreatic lipase, Phytochemical Screening, Alkaloids.

\section{Correspondence}

Dr. Rosaline Mishra ${ }^{1,2}$

'Uttarakhand Technical University, Uttarakhand, INDIA.

2ITS College of Pharmacy, College Ghaziabad, Uttar Pradesh, INDIA.

Email: rosalinemishra2@gmail.com

DOI: 10.5530/ijpi.2021.2.28

\section{INTRODUCTION}

Oxidation is basic to many living creatures for the creation of energy to fuel natural cycles. Nonetheless, the uncontrolled creations of oxygeninferred free extremists harm the cells and their capacities yet can likewise cause chain responses. Subsequently, the chain responses encourage the manufacture of new free revolutionaries. Practically all living beings are very much secured against free extremists by chemicals, for example, superoxide dismutase and catalase or dietary cancer prevention agent mixes, for example, ascorbic corrosive and tocopherols. ${ }^{1}$ At the point when the components of cell reinforcement assurance become uneven, weakening of physiological capacities may bring about degenerative or obsessive cycles, for example, maturing, malignancy, coronary heart infections, and rheumatoid joint inflammation. ${ }^{2}$ As of late, therapeutic plants have gotten a lot of consideration as wellsprings of naturally dynamic substances including cancer prevention agents, antimutagens and anticarcinogens. ${ }^{3}$ It is vital to make reference to that a huge number of normal cancer prevention agents have been disengaged from various types of plant materials, for example, oilseeds, organic products, leaves, and roots just as from various vegetables, oat yields, flavours and spices. ${ }^{4}$ Notwithstanding, logical data on cancer prevention agent properties of different plants having rare use in culinary and medication is still scant. In this way, the evaluation of such properties remains an intriguing and valuable errand, especially for finding new wellsprings of regular cell reinforcements, useful nourishments and nutraceuticals. ${ }^{5}$ Smilax zeylanica L. (Family: Smilacaceae), privately known as 'Kumarilata' in Bangladesh, is an equipped or unarmed woody climber and broadly dispersed in South Asian areas, China and a few sections in Africa. Leaves, roots and rhizomes of S. zeylanica are generally utilized

in the administration of a few infirmities. In the folkloric arrangement of medication, this plant is utilized in the treatment of venereal sicknesses, skin problems, injuries, swellings, sore and furthermore applied for stiffness and agony in lower limits. ${ }^{6}$ Additionally, it is utilized in impotency and general shortcoming. The phytoconstituents revealed in the leaves and underlying foundations of S. zeylanica are dioscin (spirostanol triglycoside) and steroidal saponin glycosides, for example, diosgenin, smilagenin and sarsapogenin. ${ }^{78}$ The roots and rhizomes of S. zeylanica have been accounted for to display antiepileptic and cancer prevention agent action, while the leaves show antidiabetic, anthelmintic and cell reinforcement potential. ${ }^{69-12}$ Murali et al. ${ }^{13}$ have distributed a paper about the methanolic concentrate of roots and rhizomes of $S$. zeylanica L. for hepatoprotective impact. In a short correspondence, Bari et al. ${ }^{14}$ have written about the chloroform and methanolic concentrate of the leaf, stem and foundation of S. zeylanica L. for pesticidal action on Cryptolestes pusillus. ${ }^{14}$ Nonetheless, as of recently no logical examination on the stems of this plant has been accounted for. Taking this in view and as a component of our continuous examination on restorative plants. ${ }^{15,16}$ our investigation was meant to assess the cell reinforcement and cytotoxic capability of the methanolic concentrates and oil ether concentrates of S. zeylanica stems. Different in vitro measure frameworks were utilized. For cancer prevention agent potential, DPPH (1,1-diphenyl2-picrylhydrazyl) free revolutionary searching measure, nitric oxide rummaging test, hydrogen peroxide searching test, cupric-diminishing cell reinforcement limit, ferric-decreasing cell reinforcement power, allout cancer prevention agent limit and assurance of all-out phenol and flavonoid content were utilized. For cytotoxic potential, saline solution 
shrimp lethality bioassay and MTT cell suitability test were utilized to comprehend the capability of this plant for use in phytomedicine. In spite of the fact that the cell reinforcement movement of roots, rhizomes and leaves from this plant has been accounted for in past investigations, this is the main report on the stem's cancer prevention agent action and cytotoxic potential.

\section{METHODS}

\section{Collection of plant material}

The plant Smilax zeylanica was collected in June from Yamuna biodiversity park, New Delhi. The formal authentication and identification was done in department of botany Ch. Charan Singh University, Meerut. The roots were allowed to air dry, away from sunlight. The dried material was grounded coarsely to a powder and transferred to labelled brown bottles until required.

\section{Extraction procedure}

The fresh and dried roots of Smilax zeylanica were crushed by using the grinder. The dried powdered drug passed through a 20 mesh sieve to remove excessive of mucilaginous hair. The dried, powdered plant material (500g) was extracted with cyclohexane, ethyl actate and methanol respectively for $72 \mathrm{hr}$ with intermittent stirring. The collected mass was subjected to drying to evaporate the excess of solvent in a rotary evaporator. The percentage yield all the extracts were calculated using the mathematical formula [Weight of the concentrated extract obtained/ Weight of the powdered plant drug taken initially $\times 100$ ].

\section{Phytochemical screening}

Preliminary Phytochemical qualitative analysis of different extracts of Smilax zeylanica indicated the presence of alkaloids, Saponins, flavanoids, tannins, phenol compounds in the extract Total phenolic content and total flavonoid content of plant extract was determined by the method described by elsewhere. ${ }^{17}$

\section{DPPH free radical assay}

The radical scavenging activity was done by already predetermined methods vis, DPPH radical scavenging assay. The results were expressed as $\%$ radical scavenging activity. $100 \mu \mathrm{l}$ of various concentrations (50-1000 $\mu \mathrm{g} / \mathrm{ml})$ of different extracts and $100 \mu \mathrm{l}$ solution of DPPH $(100 \mathrm{mM}$ in methanol) was incubated at $37^{\circ} \mathrm{C}$ for $30 \mathrm{~min}$ and change in absorbance of reaction mixture was read at $517 \mathrm{~nm}$. An equal concentration of methanol and DPPH serves as control. The experiment was performed in triplicate and percentage radical scavenging activity was calculated by formula given below: ${ }^{18}$

$\%$ of inhibition $=\underline{(A \text { of control }-\mathrm{A} \text { of test }) \times 100}$

$$
\text { A of control }
$$

\section{Preparation of Extract for in vitro Assay}

The tested extracts were initially dissolved in DMSO to give five different stock solutions with a concentration range of $0.625-10.0 \mathrm{mg} / \mathrm{mL}(0.625$, $1.25,2.5,5.0$ and $10 \mathrm{mg} / \mathrm{mL}$ ). Subsequently, $20 \mu \mathrm{L}$ aliquot of each stock solution was used in the reaction mixture to give a final concentration range of $12.5-200 \mu \mathrm{g} / \mathrm{mL}(12.5,25,50,100$ and $200 \mu \mathrm{g} / \mathrm{mL})$. Similarly orlistat was prepared as standard.

\section{Porcine pancreatic lipase inhibition assay}

Porcine pancreatic lipase, $\mathrm{p}-\mathrm{NPB}$, morpholine propane sulphonic acid, were purchased from Sigma Aldrich. Porcine pancreatic lipase (PPL) inhibitory assay was performed with minor modification. The enzyme solutions was prepared immediately before use, by suspending crude porcine pancreatic lipase powder type II (Sigma, EC 3.1.1.3) in Tris- $\mathrm{HCl}$ buffer (50 mMTris, $150 \mathrm{mMNaCl}, 1 \mathrm{mM}$ EDTA, $10 \mathrm{mM}$ MOPS, pH 7.6) to give a concentration of $5 \mathrm{mg} / \mathrm{mL}$ ( 200 units $/ \mathrm{mL}$ ). The solution was then centrifuged at $1,500 \mathrm{rpm}$ for $10 \mathrm{~min}$ and the clear supernatant was recovered. The plant extracts were then pre incubated with $200 \mu \mathrm{L}$ of PPL solution for $5 \mathrm{~min}$ at $37^{\circ} \mathrm{C}$, before the addition of $5 \mu \mathrm{L}$ PNPB substrate solution $(10 \mathrm{mM}$ in acetonitrile). The total reaction volume was made to $1 \mathrm{~mL}$ using the Tris- $\mathrm{HCl}$ buffer before measuring the absorbance at $410 \mathrm{~nm}$ against blank using denatured enzyme. The denatured enzyme was prepared by boiling the enzyme solution for $5 \mathrm{~min}$. Orlistat was used as a reference drug. The extract was dissolved in DMSO at a final concentration not exceeding $1 \%(\mathrm{v} / \mathrm{v})$ which will not affect enzyme activity.

All assays were run at $37^{\circ} \mathrm{C}$ and reported results were the average of three replicates that were blank subtracted. Orlistat was used as a positive control. DMSO was used as a negative control and the activity was also examined with and without the inhibitor. Inhibition of the lipase activity was expressed as the percentage decrease in the activity when PPL was incubated with the test compounds. Lipase inhibition (\%) was calculated according to the following formula: ${ }^{19}$

$\mathrm{I} \%=\left(\frac{B}{A}\right)^{*} 100$

Where $A$ is the activity of the enzyme without inhibitor, $B$ is the activity of the enzyme with inhibitor.

\section{RESULTS}

The percentage yield of various extracts of Smilax zeylanica was determined. The percentage yield for the cyclohexane extract was found to be $1.99 \%$, ethyl acetate extract was $2.26 \%$, Methanol extract was found to be $4.13 \%$.

The Preliminary phytochemical screening of crude methanolic extract and petroleum ether extracts of the stems of Smilax zeylanica revealed the substantial presence of Phenols, flavonoids and glycoside (Table 1).

The total Phenolic content of Smilax zeylanica cyclohexane extract was found to be $136.55 \mu \mathrm{g} / \mathrm{mg}$ of gallic acid, for ethyl acetate extract it was $187.11 \mu \mathrm{g} / \mathrm{mg}$ of gallic acid and it was highest i.e., $203.11 \mu \mathrm{g} / \mathrm{gm}$ of gallic acid for methanol extract of Smilax zeylanica. The total Flavonoid Content of Smilax zeylanica cyclohexane extract was found to be 22.06 $\mathrm{mg} / \mathrm{g}$ quercetin equivalent, for ethyl acetate extract it was $27.06 \mathrm{mg} / \mathrm{g}$ quercetin equivalent and for methanol extract of Smilax zeylanica it was $31.9 \mathrm{mg} / \mathrm{g}$ quercetin equivalent.

The extracts showed dose-dependent scavenging of DPPH radical when compared to ascorbic acid (Figure 1). The $\mathrm{IC}_{50}$ value of cyclohexane extract, ethyl acetate extract and methanolic extracts of Smilax zeylanica and petroleum ether were $35.76 \mu \mathrm{g} / \mathrm{mL}, 52.74$ and $70.43 \mu \mathrm{g} / \mathrm{ml}$, respectively, while the $\mathrm{IC}_{50}$ value for the reference ascorbic acid was 77.8 $\pm 0.24 \mu \mathrm{g} / \mathrm{ml}$.

The extracts showed dose-dependent effect in porcine pancreatic lipase inhibition assay (Figure 2). The \% Inhibition of cyclohexane extract (SZC) was $37.52 \% 54.44 \%$ and 77.07 at the highest dose $200 \mu \mathrm{g} / \mathrm{ml}$. The highest inhibition was obtained in the methanolic extract at $200 \mu \mathrm{g} / \mathrm{ml}$ conc which was close to the standard orlistat i.e., 82.39 at $200 \mu \mathrm{g} / \mathrm{ml}$.

\section{DISCUSSION}

In this study Smilax zeylanica was analysed for its potential. Primary phytochemical screening uncovered the presence of flavonoid, tannin and glycosides in both methanolic and oil ether removes. Polyphenolic mixes, similar to flavonoids, tannins and phenolic acids, ordinarily found in plants have been accounted for to have different organic impacts, including cancer prevention agent action. ${ }^{20,21}$ Flavonoids and 
Table 1: Photochemical screening of the extracts of Smilax zeylanica.

\begin{tabular}{|c|c|c|c|c|}
\hline S.No. & Phytoconstituents present & $\begin{array}{c}\text { Cyclo hexane extract of Smilax } \\
\text { zeylanica }\end{array}$ & $\begin{array}{c}\text { Ethyl acetate extract of Smilax } \\
\text { zeylanica }\end{array}$ & $\begin{array}{c}\text { Methanol extract of Smilax } \\
\text { zeylanica }\end{array}$ \\
\hline 1. & Alkaloids & $(+)$ & $(+)$ & $(+)$ \\
\hline 2. & Tannins & $(+)$ & $(+)$ & $(+)$ \\
\hline 3. & Saponins & $(+)$ & $(++)$ & $(++)$ \\
\hline 4. & Proteins & $(-)$ & $(+)$ & $(+)$ \\
\hline 5. & Flavanoids & $(+)$ & $(++)$ & $(++)$ \\
\hline 6. & Carbohydrates & $(-)$ & $(-)$ & $(+)$ \\
\hline 7. & Anthraquinones & $(+)$ & $(+)$ & $(-)$ \\
\hline 8. & Phenols & $(+)$ & $(+)$ & $(+)$ \\
\hline 9. & Steroids & $(-)$ & $(+)$ & $(+)$ \\
\hline
\end{tabular}

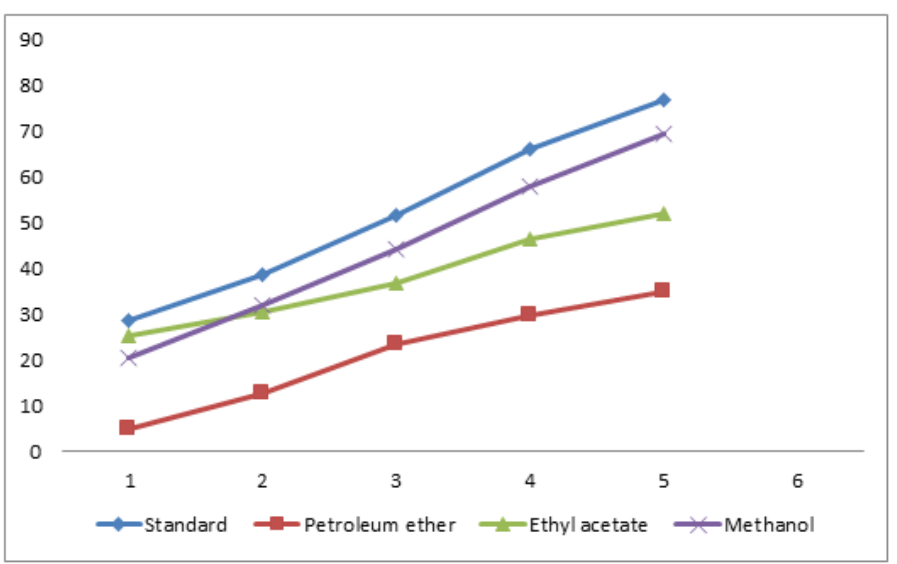

Figure 1: DPPH \%age free radical- scavenging capacity for standard and extracts of Smilax zeylanica

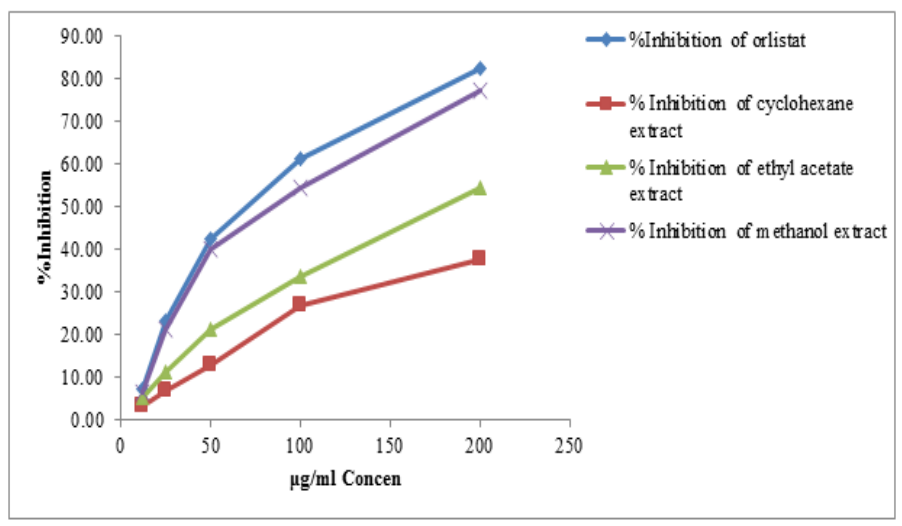

Figure 2: Porcine pancreatic lipase inhibition of Smilax zeylanica extracts.

tannins present in the plant extricates, as apparent from phytochemical screening, might be principally answerable for the antioxidant activity. Free extremists significantly affect the oxidation of unsaturated lipids. The DPPH revolutionary was utilized as a steady free extremist to decide pancreatic lipase activity. ${ }^{22}$ The DPPH cell reinforcement measure depends on the capacity of DPPH, a steady free extremist, to decolorize within the sight. The odd electron in the DPPH revolutionary is liable for the absorbance at $517 \mathrm{~nm}$ and furthermore for the noticeable profound purple tone..$^{23}$ Along these lines, one of the potential components of methanolic remove's solid antiradical action may be described to the presence of a decent measure of phenolic and flavonoidal substance. Nitric oxide or responsive nitrogen species, shaped during their response with oxygen or superoxide's are receptive. ${ }^{24}$ Hydrogen peroxide itself isn't responsive, yet it can in some cases be harmful on the grounds that it might offer ascent to hydroxyl extremists in cells. ${ }^{25}$ Flavonoids have been appeared to shield mammalian and bacterial cells from cytotoxicity by hydrogen peroxide restraint, particular extracts with the o-dihydroxy phenolic structure. ${ }^{26}$ Pancreatic lipase is a vital compound for lipid ingestion by hydrolysis of all out dietary fats. Consequently, the examination of new specialist for pancreatic lipase inhibitor is as yet required. Our finding is the first run showed solid enemy of lipase action. This recommends that these spices appear to be promising as the inhibitor of pancreatic lipase. Our outcomes indicating a critical positive relationship between are phenolic, flavonoid, alkaloid substance and restraint action, which offer solid help that these phytochemical are key for pancreatic lipase activity. The study performed showed that the plant has shown the capacity of pancreatic lipase movement. Distributed exploration additionally detailed that flavonoids and alkaloid have the potential for pancreatic lipase activity. We inferred that Smilax zeylanica acted as key specialists for pancreatic lipase hindrance in vitro.

\section{CONCLUSION}

The methanolic extracts could be considered as potential sources of natural antioxidant. It also showed potential pancreatic lipase inhibition could be explored for antilipidemic potential.

\section{ACKNOWLEDGEMENT}

The author acknowledges the I.T.S College of Pharmacy, Ghaziabad.

\section{CONFLICT OF INTEREST}

The authors declare that there is no conflict of interest.

\section{ABBREVIATIONS}

DPPH: 2,2-diphenyl-1-picrylhydrazyl; Porcine assay: Porcine pancreatic lipase inhibition assay; SZC: Cyclohexane extract; SZE: Ethyl acetate extract; SZM: Methanol extract.

\section{REFERENCES}

1. Sies H. Oxidative stress: Oxidants and antioxidants. Exper Physiol. 1997;82(2):291-5.

2. Halliwell B, Gutteridge J. Oxygen toxicity, oxygen radicals, transition metals and disease. Bioche J. 1984;219(1):41.

3. Dillard CJ, German JB. Phytochemicals: Nutraceuticals and human health. J Sci Food Agric. 2000;80(12):744-56. 
4. Ramarathnam N, Osawa T, Ochi H, Kawakishi S. The contribution of plant food antioxidants to human health. Trends Food Sci Tech. 1995;6(3):75-82.

5. Miliauskas G, Venskutonis PR, van Beek TA. Screening of radical scavenging activity of some medicinal and aromatic plant extracts. Food Chem. 2004;85(2):231-7.

6. Madhavan V, HemalathaTH, Murali A, Yoganarasimhan SN. Antiepileptic activity of alcohol and aqueous extracts of roots and rhizomes and Smilax zeylanica Linn. Pharmacol Online. 2008;3:263-72.

7. Evans WC. Trease and Evans pharmacognosy, $15^{\text {th }}$ ed. Edinburgh, New York: WB Saunders; 2002;480.

8. Kar DK, Sen S. Smilax zeylanica Linn.: A new source of diosgenin. Curr Sci. 1984;53(12):661.

9. Rajesh V, Perumal P, Sundarrajan T. Antidiabetic activity of methanolic extract of Smilax zeylanica Linn. in streptozotocin induced diabetic rats. Intern J Pharmacol. 2010;6(1):9.

10. Rajesh V, Perumal P, Chinthakindhi V, Prabhakaran S, Hymavathi G, Guntupalli T. In vitro evaluation of Smilax zeylanica Linn. leaves for anthelmintic activity. Internet J Pharmacol. 2010;9(10.5580):797.

11. Murali A, Ashok P, Madhavan V. In vitro antioxidant activity and HPTLC studies on the roots and rhizomes of Smilax zeylanica L.(Smilacaceae). Int J Pharm Pharm Sci. 2011;3(1):192-5.

12. Thirugnanasampandan $\mathrm{R}$, Mutharaian $\mathrm{V}$, Bai $\mathrm{VN}$. In vitro propagation and free radical studies of Smilax zeylanica Vent. Afr J Biotechnol. 2009;8(3):395-400.

13. Murali A, Ashok P, Madhavan V. Screening of methanol extract of roots and rhizomes of Smilax zeylanica $L$ for hepatoprotective effect against carbontetrachloride induced hepatic damage. J Exp Integr Med. 2012;2:237-44.

14. Bari M, Islam W, Khan A. Pesticidal activity of Smilax zeylanica L. extracts on Cryptolestes pusillus (Schon.)(Coleoptera: Cucujidae). J Bangladesh Acad Sci. 2010;10:205-8.

15. Ahmed T, Uddin MN, Ahmed SF, Saha A, Farhana K, Rana MS. In vitro evaluation of antioxidant potential of Artocarpus chama Buch fruits. J App Pharm Sci.
2012;2(10):75- 80 .

16. Hasan R, Hossain M, Akter R, Jamila M, Mazumder EH, Islam I, et al. Antioxidant, antidiarrhoeal and cytotoxic properties of Punica granatum Linn. Latin Am J Pharm. 2009;28(5):783-8.

17. Singh J, Parasuraman S, Kathiresan S. Antioxidant and antidiabetic activities of methanolic extract of Cinnamomum cassia. Phcog Res. 2018;10(3):237-42.

18. Ichikawa K, Sasada R, Chiba K, Gotoh H. Effect of side chain functional groups on the DPPH radical scavenging activity of bisabolane-type phenols. Antioxidants. 2019;8(3):65.

19. Gil MI, Ferreres F, Tomás-Barberán FA. Effect of postharvest storage and processing on the antioxidant constituents (flavonoids and Vitamin c) of freshcut spinach. J Agric Food Chem. 1999;47(6):2213-7.

20. Kähkönen MP, Hopia Al, Vuorela HJ, Rauha JP, Pihlaja K, Kujala TS, et al. Antioxidant activity of plant extracts containing phenolic compounds. J Agric Food Chem. 1999;47(10):3954-62

21. Shimada K, Fujikawa K, Yahara K, Nakamura T. Antioxidative properties of xanthan on the autoxidation of soybean oil in cyclodextrin emulsion. J Agric Food Chem. 1992;40(6):945-8.

22. Yokozawa T, Chen CP, Dong E, Tanaka T, Nonaka GI, Nishioka I. Study on the inhibitory effect of tannins and flavonoids against the 1, 1-diphenyl-2picrylhydrazyl radical. Biochem Pharmacol. 1998;56(2):213-22.

23. Moncada S, Palmer RM, Higgs EA. Nitric oxide: Physiology, pathophysiology and pharmacology. Pharmacol rev. 1991;43:109-42.

24. Halliwell B. Reactive oxygen species in living systems: Source, biochemistry, and role in human disease. Am J Med. 1991;91(3):S14-22.

25. Tsutomu N, Munetaka Y, Toshihiko O, Shunro K. Suppression of active oxygeninduced cytotoricity by flavonoids. Biochem Pharmacol. 1993;45(1):265-7.

26. Alias N, LeowTC, Ali MS, Tajudin AA, Salleh AB, RNZRA R. Anti-obesity potential of selected tropical plants via pancreatic lipase inhibition. Advances in Obesity, Weight Management and Control. 2017;6(4):6.

Article History: Submission Date : 22-02-2021; Revised Date : 14-03-2021; Acceptance Date : 02-04-2021.

Cite this article: Mishra R, Juyal D, Kumar SS. Assessment of Antioxidant and Pancreatic Lipase Activity of Smilax zeylanica Roots: An in vitro Analysis. Int. J. Pharm. Investigation, 2021;11(2):154-7. 